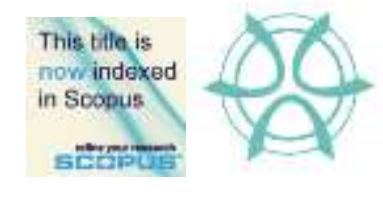

\title{
THE IMPLEMENTATION OF STANDARD APPROACH FOR OPEN SPACE PLANNING IN KUALA LUMPUR
}

\author{
Robiah Suratman ${ }^{1}$, Maryanti Mohd Raid ${ }^{2}$, Muhammad Izuan Nadzri ${ }^{3}$, Salfarina \\ Samsudin $^{4}$, Nur Khairiyah Mohammad \\ 1,2,4,5 Faculty of Built and Environment \\ UNIVERSITI TEKNOLOGI MALAYSIA \\ ${ }^{3}$ Institute of Oceanography and Environment (INOS) \\ UNIVERSITI MALAYSIA TERENGGANU
}

\begin{abstract}
This article attempts to discuss the implementation of standards approach, 2 hectares per 1000 population as approved by the National Physical Planning Council in 2005. Using Kuala Lumpur as case study, the analysis showed that the uniformity of standards approach implementation has failed to take into account the distinction within the local conditions which have implications on the level of achievement for the 6 planning zones in Kuala Lumpur from 2011 to 2017. Use of the standards approach without modifications has created high density zones such as the City Centre, Sentul-Manjalara and Wangsa Maju-Maluri failed to attain the standards. Besides, other zones namely Damansara-Penchala, Bandar Tun Razak-Sungai Besi and Bukit Jalil-Seputih have exceeded the targeted standards. Based on the analysis, the distinction of local condition for each zone in Kuala Lumpur in terms of population number, urban land availability, land value, urbanization process and densification rate of the city need to be considered in implementing standards approach.
\end{abstract}

Keyword: open space planning, standards approach, open space provision, high density city

\footnotetext{
${ }^{2}$ Corresponding Author \& Research Officer at Universiti Teknologi Malaysia. Email: maryantimohdraid@gmail.com
} 
PLANNING MALAYSIA

Journal of the Malaysia Institute of Planners (2020

\section{INTRODUCTION}

Standards approach has evolved through time and has been used worldwide as one of the conventional methods in providing open space. The trajectory of standards approach begins in United Kingdom, the pioneer country in adopting the standards approach since the late 1800s (Theobald, 1984; Veal, 2013). Since then, this approach became the vital part of open space planning policy to ensure the adequacy of opens space quantity to be provided for each of the citizen in fulfilling their social needs. It is known that the provision of open space is essential to improve the quality of life as it offers various benefits in terms of social, environment, economic and aesthetic value of urban living and surrounding (Givoni, 1991; Torkildsen, 2005; Heidt dan Neef, 2008; Lee et al., 2015). Thus, the provision of open space is necessary to strengthen the efforts of the local authority to create a liveable city and encourage urban development towards sustainability framework.

\section{RESEARCH BACKGROUND}

In Malaysia, the importance of providing open space was initiated by the government since the idea to transform Malaysia into Garden City has emerged as a response to the Langkawi Declaration in 1989 and national commitment in rationalizing Agenda 21 in 1992 (Ismail, 1999). Open space must be part of the national environmental equilibrium agenda in achieving strong economic growth (Tahir, 1997). Thus, the provision of open space should not be taken as an afterthought but as part of the vital component of urban planning that need to be taken into account. This idea has been a core focus in the previous Economic Transformation Program (ETP) to encourage the provision for additional parks and tree planting through National Landscape Department to make Kuala Lumpur as an attractive place to work, live and invest (PEMANDU, 2012).

In 2005, a target of 2 hectare per 1000 population was approved and established by National Physical Planning Council (NPPC) to monitor the adequacy of open space provision towards developed country by the year 2020 . The targeted standards established was at par with the international standards from other high density city such as Washington (4.57 hectare per 1000 population), San Francisco (3.23 hectares per 1000 population), Stockholm (8.03 hectares per 1000 population) and Amsterdam (2.97 hectares per 1000 population). In 2006, the first National Urbanization Policy (2006-2015) has adopted the target under its DPN9; adequate open space and recreation area should be provided according to the needs of the residents through the application of the target of 2 hectares per 1000 urban residents. Then, the need to increase the quantity of open space continues to be emphasized in the NUP 2 (2016-2025) as one of the efforts to create a safe, clean and comfortable neighbourhood with a low carbon lifestyle (JPBD Peninsular Malaysia, 2016). 
Robiah Suratman, Maryanti Mohd Raid, Muhammad Izuan Nadzri, Salfarina Samsudin, Nur Khairiyah Mohammad

The Implementation of Standards Approach for Open Space Planning in Kuala Lumpur

However, adoption of the standards approach has created a dilemma especially among local authorities, while some policy implementers doubt the accomplishment of this target particularly for high-density cities. In Kuala Lumpur, the city is struggling to develop new open space while the quantity of existing open space has decreased in number and size (Noor et al., 2013). Until recently, little has been written specifically on standards approach implementation in Malaysia as one of the methods to measure the adequacy of open space provision specifically in high density city context. Thus, this paper attempts to demonstrate and discuss the results of the standards approach implementation in Kuala Lumpur as reference to improve open space planning method in the future.

\section{LOCAL CONDITION ISSUE IN THE IMPLEMENTATION OF STANDARDS APPROACH}

In open space planning, methods such as standards are frequently used as conventional planning guideline to determine the adequacy of open space provision in terms of quantity and types of open space should be provided. It is supposed to be a flexible guideline and supported by several important variables such as user preferences, leisure objectives, recreation experiences, time horizon, economic feasibility, political efficiency and other related elements (Theobald, 1984; Wilkinson, 1985). Butler (1962) and Gold (1973) asserts that standards approach is only appropriate to be applied for a small area with specific population. Uniformity of its implementation to all areas will ignore the uniqueness of the local conditions in terms of size of the area, total population, land availability, urban space limitation and many others (Butler, 1962; DCLG, 2002). As the result, the quantity of open space provision should be varied depends on its local condition.

Standards approach determine by the number of population and the area of open space provision. The size of open space area must exceed the number of population to achieve the target. However, the common result frequently demonstrates that the area of open space provision is decreasing while the number of population is rising (Noor et al., 2013; Kanniah, 2017). Theoretically, the area will not attain the targeted standards and even suffering from inadequate open space provision. According to Shen et al. (2013), urbanisation process will cause the number of population to rise, change in land use while size and quantity of open space provision decreased. Due to land scarcity, urban land is facing a great pressure between the need to provide socio-economic infrastructure and the need to preserve recreational space. This competition will give ways to more economically viable development and ignore the qualitative value of open space as an important element for quality of life and sustainable urban development (Yaakup et al., 2000; Wong dan Chen, 2008; Sheng dan Thuzar, 2012; Jim, 2013; Haaland dan van den Bosch, 2015). 
The inability of open space and green areas to compete in open market has resulted to the declining of open space quantity and size in urban fabric (Cowen, 1992; Vining dan Weimer, 1992; Morriss dan Meiners, 2000; Maruani dan Amit-Cohen, 2007). This issue become more difficult to local authorities to provide adequate open space in accordance to the growing population (Nelson, 1990). Rapidly increasing demand for urban land will put green area and open space at risk of deprivation. Yaakup et al. (2000) indicate that the expansion of built up area in Klang Valley around 1988 to 1998 has destroyed $70 \%$ of agricultural and forest area. While Noor et al. (2013) has demonstrate that the expansion of built up area in Kuala Lumpur has cause $70 \%$ of green space area has been deteriorated.

Other constraint faces by local authority that administered high density city to achieve targeted standards is due to urban space limitation that caused open space and green area smaller in size due to the development pressure that took place around the area. Unavailability and inappropriate site as well as high land value has made it difficult for local authority to build new open space in a dense urban environment. These factors implicated that the open space planning in Kuala Lumpur would have problems such as new open space is difficult to be provided while the quantity of existing open space has decreased in number and size (Jim, 2004; Byrne et al., 2010; Ng et al., 2012; Tian et al., 2012).

\section{METHODOLOGY}

In this study, Kuala Lumpur was selected as case study. It comprises of six 6 planning zones namely Sentul-Manjalara, Damansara-Penchala, Bukit JalilSeputih, Bandar Tun Razak-Sungai Besi, Wangsa Maju-Maluri and City Center. Comparison of green area cover for the six planning zones were carried out to examine the achievement of standards approach in 2011 and 2017 using data from satellite imagery as the ancillary data. Multitemporal imagery used allows the changes to be distinguished thus correlated with the Kuala Lumpur City Hall (KLCH) statistics evidently. Then, in-depth interview with four respondents comprising officers from the policy implementer's agencies at the federal and local level were carried out to identify the factors that derived the distinction of achievement for the six planning zones in Kuala Lumpur. Then the data were analysed using Nvivo 11 software. All the respondents involved in this study are described in Table 1 below. 
Robiah Suratman, Maryanti Mohd Raid, Muhammad Izuan Nadzri, Salfarina Samsudin, Nur Khairiyah Mohammad The Implementation of Standards Approach for Open Space Planning in Kuala Lumpur

Table 1: List of respondent involved in this study.

\begin{tabular}{|c|c|c|c|}
\hline $\begin{array}{l}\text { Responden } \\
\text { Code }\end{array}$ & $\begin{array}{l}\text { Job } \\
\text { Position }\end{array}$ & Agency & $\begin{array}{c}\text { Level of } \\
\text { involvement }\end{array}$ \\
\hline R1 & $\begin{array}{l}\text { Deputy } \\
\text { Diector }\end{array}$ & $\begin{array}{c}\text { Property Management and } \\
\text { Valuation, Kuala Lumpur City } \\
\text { Hall }\end{array}$ & \multirow{2}{*}{$\begin{array}{l}\text { Policy implementer } \\
\text { in local level }\end{array}$} \\
\hline $\mathbf{R 2}$ & $\begin{array}{l}\text { Deputy } \\
\text { Director }\end{array}$ & $\begin{array}{l}\text { City Planning Department, } \\
\text { Kuala Lumpur City Hall }\end{array}$ & \\
\hline R3 & $\begin{array}{l}\text { Chief } \\
\text { Deputy } \\
\text { Director }\end{array}$ & $\begin{array}{l}\text { Research and Development } \\
\text { PLANMalaysia }\end{array}$ & \multirow{2}{*}{$\begin{array}{l}\text { Policy implementer } \\
\text { in federal level }\end{array}$} \\
\hline R4 & Director & $\begin{array}{c}\text { Policy Sector } \\
\text { National Landscape } \\
\text { Department }\end{array}$ & \\
\hline
\end{tabular}

\section{RESEARCH FINDINGS AND DISCUSSIONS}

Although overall achievement of Kuala Lumpur has exceeded the targeted standards, however the achievement of the six planning zones in Kuala Lumpur is varied. From Table 2 below, the analysis demonstrates that high density zones such as the City Centre, Sentul-Manjalara and Wangsa Maju-Maluri have failed to attain the standards. While other zones namely Damansara-Penchala, Bandar Tun Razak-Sungai Besi and Bukit Jalil-Seputih have exceeded the targeted standards.

Table 2: The achievement of zones in Kuala Lumpur in attaining targeted standards of 2 hectare per 1000 population.

\begin{tabular}{llccc}
\hline \multirow{2}{*}{ Zone } & \multicolumn{2}{c}{$\begin{array}{c}\text { Achievement } \\
\text { (hectare/1000 population) }\end{array}$} & \multirow{2}{*}{ Status } \\
\cline { 3 - 4 } & & $\mathbf{2 0 1 1}$ & $\mathbf{2 0 1 7}$ & \\
\hline Kuala Lumpur & $\mathbf{2 . 4 8}$ & $\mathbf{2 . 3 1}$ & \multirow{2}{*}{ Achieved } \\
\hline 1. & Damansara-Penchala & 6.08 & 5.20 & \multirow{2}{*}{ Exceed } \\
\cline { 1 - 3 } 2. & Bandar Tun Razak-Sungai Besi & 2.14 & 2.37 & \\
\cline { 1 - 3 } 3. & Bukit Jalil-Seputih & 2.30 & 2.12 & \\
\cline { 1 - 3 } 4. & Sentul-Manjalara & 1.40 & 1.73 & \multirow{2}{*}{ Not achieved } \\
\cline { 1 - 3 } 5. & Wangsa Maju-Maluri & 1.58 & 1.59 & \\
\hline 6. & Pusat Bandar & 1.43 & 0.89 & \\
\hline
\end{tabular}

The results of the analysis are also in line with the declining of green area distribution for each of the zone from 2011 to 2017 as showed and described in Figure 1 and Table 3 below. 

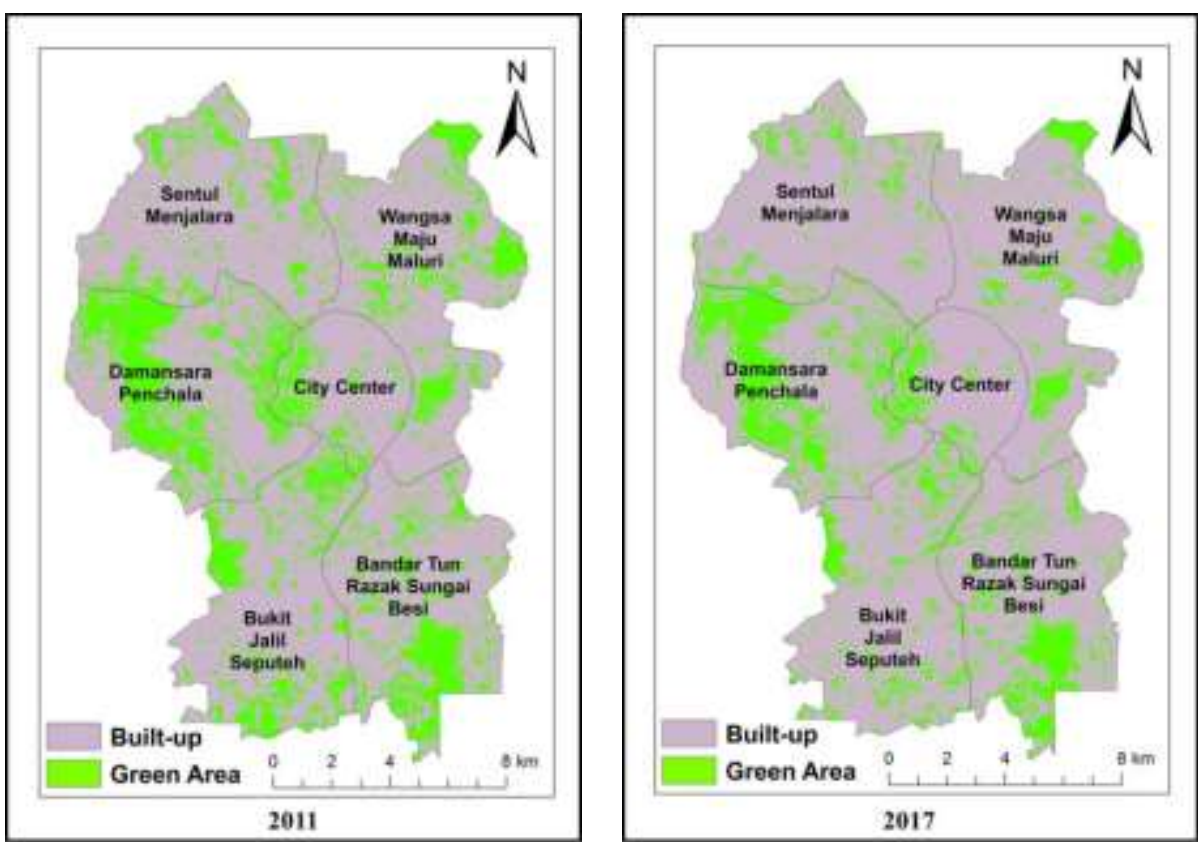

Figure 1: Green area distribution in Kuala Lumpur for 2011 and 2017.

Table 3: Green space area distribution and the achievement of standards of each zones in Kuala Lumpur in 2011 and 2017.

\begin{tabular}{|c|c|c|c|}
\hline Zone & Year & 2011 & 2017 \\
\hline \multirow[t]{5}{*}{ City Center } & Total of population & 148,001 & 164,547 \\
\hline & Green space area & $\begin{array}{c}211.38 \text { hectare } \\
(11.66 \%)\end{array}$ & $\begin{array}{c}146.12 \text { hectare } \\
(8.06 \%)\end{array}$ \\
\hline & Built up area & $\begin{array}{c}1,601.62 \text { hectare } \\
(88.34 \%)\end{array}$ & $\begin{array}{c}1,666.88 \text { hectare } \\
(91.94 \%)\end{array}$ \\
\hline & Total area & \multicolumn{2}{|c|}{1,813 hectare $(100 \%)$} \\
\hline & $\begin{array}{l}\text { Achievement of } \\
\text { standards }\end{array}$ & $\begin{array}{c}1.43 \text { hectare/ } \\
1000 \text { population }\end{array}$ & $\begin{array}{c}0.89 \text { hectare/ } \\
1000 \text { population }\end{array}$ \\
\hline Zone & Year & 2011 & 2017 \\
\hline \multirow{5}{*}{$\begin{array}{l}\text { Wangsa } \\
\text { Maju- } \\
\text { Maluri }\end{array}$} & Total of population & 416,131 & 432,677 \\
\hline & Green space area & $\begin{array}{c}658.52 \text { hectare } \\
(14.27 \%)\end{array}$ & $\begin{array}{c}686.57 \text { hectare } \\
14.88 \%)\end{array}$ \\
\hline & Built up area & $\begin{array}{c}3,955.48 \text { hectare } \\
(85.73 \%)\end{array}$ & $\begin{array}{c}3,927.43 \text { hectare } \\
(85.12 \%)\end{array}$ \\
\hline & Total area & \multicolumn{2}{|c|}{4,614 hectare $(100 \%)$} \\
\hline & $\begin{array}{l}\text { Achievement of } \\
\text { standards }\end{array}$ & $\begin{array}{c}1.58 \text { hectare/ } \\
1000 \text { population }\end{array}$ & $\begin{array}{c}1.59 \text { hectare/ } \\
1000 \text { population }\end{array}$ \\
\hline
\end{tabular}


Robiah Suratman, Maryanti Mohd Raid, Muhammad Izuan Nadzri, Salfarina Samsudin, Nur Khairiyah Mohammad The Implementation of Standards Approach for Open Space Planning in Kuala Lumpur

\begin{tabular}{|c|c|c|c|}
\hline Zone & Year & 2011 & 2017 \\
\hline \multirow{5}{*}{$\begin{array}{l}\text { Sentul- } \\
\text { Manjalara }\end{array}$} & Total of population & 363,449 & 379,995 \\
\hline & Green space area & $\begin{array}{c}508.33 \text { hectare } \\
(10.92 \%)\end{array}$ & $\begin{array}{c}657.78 \text { hectare } \\
(14.12 \%)\end{array}$ \\
\hline & Built up area & $\begin{array}{c}4,148.67 \text { hectare } \\
(89.08 \%)\end{array}$ & $\begin{array}{c}3,999.22 \text { hectare } \\
(85.88 \%)\end{array}$ \\
\hline & Total area & \multicolumn{2}{|c|}{4,657 hectare $(100 \%)$} \\
\hline & $\begin{array}{l}\text { Achievement of } \\
\text { standards }\end{array}$ & $\begin{array}{c}1.40 \text { hectare/ } \\
1000 \text { population }\end{array}$ & $\begin{array}{c}1.73 \text { hectare/ } \\
1000 \text { population }\end{array}$ \\
\hline Zone & Year & 2011 & 2017 \\
\hline \multirow{5}{*}{$\begin{array}{l}\text { Damansara- } \\
\text { Penchala }\end{array}$} & Total of population & 179,289 & 195,835 \\
\hline & Green space area & $\begin{array}{c}1,090.19 \text { hectare } \\
(24.12 \%)\end{array}$ & $\begin{array}{c}1,018.85 \text { hectare } \\
(22.54 \%)\end{array}$ \\
\hline & Built up area & $\begin{array}{c}3,429.81 \text { hectare } \\
(75.88 \%)\end{array}$ & $\begin{array}{c}3,501.15 \text { hectare } \\
(77.46 \%)\end{array}$ \\
\hline & Total area & \multicolumn{2}{|c|}{4,520 hectare $(100 \%)$} \\
\hline & $\begin{array}{l}\text { Achievement of } \\
\text { standards }\end{array}$ & $\begin{array}{c}6.08 \text { hectare/ } \\
1000 \text { population }\end{array}$ & $\begin{array}{c}5.20 \text { hectare/ } \\
1000 \text { population }\end{array}$ \\
\hline Zone & Year & 2011 & 2017 \\
\hline \multirow{5}{*}{$\begin{array}{l}\text { Bandar Tun } \\
\text { Razak- } \\
\text { Sungai Besi }\end{array}$} & Total of population & 304,099 & 320,645 \\
\hline & Green space area & $\begin{array}{c}650.02 \text { hectare } \\
(15.37 \%)\end{array}$ & $\begin{array}{c}760.31 \text { hectare } \\
(17.98 \%)\end{array}$ \\
\hline & Built up area & $\begin{array}{c}3,577.98 \text { hectare } \\
(84.63 \%)\end{array}$ & $\begin{array}{c}3,467.69 \text { hectare } \\
(82.02 \%)\end{array}$ \\
\hline & Total area & \multicolumn{2}{|c|}{4,228 hectare $(100 \%)$} \\
\hline & $\begin{array}{l}\text { Achievement of } \\
\text { standards }\end{array}$ & $\begin{array}{c}2.14 \text { hectare/ } \\
1000 \text { population }\end{array}$ & $\begin{array}{c}2.37 \text { hectare/ } \\
1000 \text { population }\end{array}$ \\
\hline Zone & Year & 2011 & 2017 \\
\hline \multirow{5}{*}{$\begin{array}{l}\text { Bukit Jalil- } \\
\text { Seputih }\end{array}$} & Total of population & 283,533 & 320,645 \\
\hline & Green space area & $\begin{array}{l}652.85 \text { hectare } \\
(14.87 \%)\end{array}$ & $\begin{array}{c}\text { 635.81 hectare } \\
(14.48 \%)\end{array}$ \\
\hline & Built up area & $\begin{array}{c}3,737.15 \text { hectare } \\
(84.13 \%)\end{array}$ & $\begin{array}{c}3,754.19 \text { hectare } \\
(85.52 \%)\end{array}$ \\
\hline & Total area & \multicolumn{2}{|c|}{4,390 hectare $(100 \%)$} \\
\hline & $\begin{array}{l}\text { Achievement of } \\
\text { standards }\end{array}$ & $\begin{array}{c}2.30 \text { hectare/ } \\
1000 \text { population }\end{array}$ & $\begin{array}{c}2.12 \text { hectare/ } \\
1000 \text { population }\end{array}$ \\
\hline
\end{tabular}

From the result of the analysis as described in Table 3 confirmed that the uniformity of standards approach implementation in Kuala Lumpur has failed to take into account the distinction of local conditions which have implications on the level of achievement for the 6 planning zones in Kuala Lumpur from 2011 
to 2017. The distinction within local conditions were identified in terms of population number, limited and decreasing urban land availability, high land value, urbanization process and high densification rate of the city.

\section{Population Number}

Based on the interview, all respondents agree that the difficulty to achieve the targeted standards is due to the growing number of population that leads to insufficient of open space provision in certain area in Kuala Lumpur. From the statistic of urban population provide by Kuala Lumpur City Hall in 2011 to 2017, City Centre experienced the highest percentage of population grows with $10 \%$, followed by Damansara-Penchala (8\%), Bukit Jalil-Seputih (6\%), Bandar Tun Razak-Sungai Besi (5\%), Sentul-Manjalara (4\%) and Wangsa Maju-Maluri $(3.8 \%)$. The respond from all the respondents is detailed in Table 4 below.

Table 4: Respond from respondent R1, R2, R3 and R4 regarding population number in Kuala Lumpur.

Responden
R1
"It's difficult for us to provide sufficient open space in City Centre area.
The growing number of population causes the need to provide open
space increase but there's no available land to build new open space
and it's not the current priority compared to economic development...".
"Indeed, the population number for each of the zones in Kuala Lumpur
is increasing and cause development intensifying thus affecting the
quantity of our open space especially in City Centre area..."
"Indeed, the factor of high population will make it difficult for high
density city to provide adequate open space. They (local authorities)
will be struggling and face challenges...".
"Because the urban population is growing [...] if we take a look at
Japan as one of the developed countries, they impose one child policy
to help the government to predict population. But we (Malaysia) don't
have such policy. And if you look at the projection of the world's
population, in the next 5 or 10 years, $75 \%$ of the population will live in
the city. Therefore, the city of Kuala Lumpur, especially the densely
populated zones, must struggle to provide open space which is not
enough compared to the growing population...".

\section{Limited and Decreasing Urban Land Availability}

For City Centre area, limited and decreasing urban land availability has led to the decreasing in achievement of targeted standards from 1.43 hectare per 1000 population in 2011 to 0.89 hectare per 1000 population in 2017 (Table 3). All respondents responded that the decreasing due to the increment of built up area caused open space declined in 2011 to 2017 compared to other zone. The respond from all the respondents is detailed in Table 5 below. 
Robiah Suratman, Maryanti Mohd Raid, Muhammad Izuan Nadzri, Salfarina Samsudin, Nur Khairiyah Mohammad The Implementation of Standards Approach for Open Space Planning in Kuala Lumpur

Table 5: Respond from respondent R1, R2, R3 and R4 regarding limited and decreasing urban land availability

Responden
"NUP set targeted standards in open space provision, but Kuala
Lumpur is facing land scarcity [...] it's difficult for KLCH to allocate
open space in urban fabric due to limitation of land [...] There's case
where developer has allocated buffer zone for approximately 1 acre.
Since land is limited, the buffer zone has been utilized to develop
affordable housing. We can't reject the project since the developer
willing to assist government program. Thus we have to admit and
approve the application..."
"Even though we have reserved Pudu Ulu Park, but we don't have much
choice to take it some of the land due to land scarcity. Especially today
government has launch affordable home program. Looking at the
acreage of open space in City Centre area, it's decreasing..."
"It is true that the provision of open space is not profitable and the
provision is solely for the planning purposes. Since economic
development is more profitable, then limited land resources have to
focus on infrastructure development rather than the provision of open
space. This situation will certainly affect the quantity of open space that
is declining..."
"Talking about Kuala Lumpur, of course the city is facing land scarcity
issue [...] land will never expand and everybody wants to own land [...]
for me, the standards is inapplicable for any area that having this issues.
The area will definitely have to struggle to achieve the target..."

\section{High Land Value}

According to all respondents, high land value has made available land in Kuala Lumpur were developed with economically viable development instead of open space provision. Respondent R1 stated, the reason why affordable housing is developed on open space area is due to low land value and cost saving. While respondent R2 stated that high land value has caused developer eager to obtain maximum profit and thus, any uneconomically viable development such as open space will be ignored although it is part of the planning procedure. Respondent $\mathrm{R} 3$ relate that the declining of open space area in size and quantity is due to the rapid development especially in City Centre area. While respondent R4 stated that although there will be vacant land, it does not mean that the land will be utilized for open space purposes. But the land will definitely be utilized for more economically viable development. From the respond, it can be derived that this factor has implicated the achievement of targeted standards in high density zone such as City Centre that available land will be utilized to develop more profitable development compared to open space provision. 


\section{High Densification Rate and Urbanization Process}

From the interview, findings indicate that all respondents agree that high densification rate and urbanisation process will deter several zones in Kuala Lumpur from achieving targeted standards. Based on the statistic of population densification rate in Kuala Lumpur from 2011 to 2017 provided by KLCH, it was found that Wangsa Maju-Maluri has the highest population densification rate with 9,377.49 population per kilometres followed by City Centre $(9,075.97$ population per kilometres), Sentul-Manjalara (8,159.66 population per kilometres), Bandar Tun Razak-Sungai Besi (7,583.85 population per kilometres), Bukit Jalil-Seputih (6,835.52 population per kilometres) and Damansara-Penchala (4,332.64 population per kilometres). The result obtained is found to be aligned with the analysis as showed in Table 3 that Wangsa MajuMaluri and City Centre were among the zones that failed to achieve targeted standards. The comment and respond from the respondent regarding this factor is detailed in Table 6 below.

Table 6: Respond from R1, R2, R3 and R4 regarding high densification rate and urbanisation process in Kuala Lumpur.

Responden Respond
R1 "There's a lot of government policy that made us (KLCH) difficult to
implement it in Kuala Lumpur such as NUP due to land scarcity. The
implementation of the policy will deter us from making development. In
this situation, we must go towards quality instead of quantity..."
"People ask to convert. If we don't approve, they do it anyway. For
example, open space in Jalan Maarof has been converted from open
space to residential with a claim that they don't use it..."
"The government need to be strict in preserving open space. If the state
government does not allow it and wants to retain the area as open space,
the area can be protected. Therefore, state government must be firmed
in protecting open space from being destroyed by development. For me,
the targeted standards can be achieved provided that the state
government must put some effort and being firm but this is not
happening..."
"In my opinion, we cannot measure the current situation through
quantifying the provision of open space which very difficult especially
for high density city like Kuala Lumpur. Maybe we can improve the
quantity but we need a comprehensive plan to manage urbanisation
effectively, which is very difficult since we don't have any at the
moment..."

\section{CONCLUSION}

From the findings, it can be derived that the implementation of standards approach in Kuala Lumpur is inconsistent with the standards approach principle as recommended by Butler (1962); Gold (1973); Wilkinson (1985); Scottish 
Robiah Suratman, Maryanti Mohd Raid, Muhammad Izuan Nadzri, Salfarina Samsudin, Nur Khairiyah Mohammad The Implementation of Standards Approach for Open Space Planning in Kuala Lumpur

Government (2008); Byrne dan Sipe (2010); Veal (2013). Standards approach do not possess flexibility element to adapt to different local conditions in every area (Wilkinson, 1985). It assumes that each area is similar in characteristics but the fact that they are different (Veal, 2013) in terms of population number, limited and decreasing urban land availability, high land value, urbanization process and high densification rate of the city as found in this study. Standards can be used as a guide or benchmark to begin with, but modifications of the standards according to its local conditions are essential to ensure the effectiveness of its implementation. In this situation, standards that are difficult to be achieved is considered unrealistic as well as contrary to the principles of its application (Butler, 1958; Wilkinson, 1988). Therefore, the principle of standard approach suggests that standard approach should be implemented in a specific area so that an appropriate standard target can be determined as well as assisting local authorities in establishing a comprehensive and effective greening program and action plan to increase the quantity of open space in the area.

\section{ACKNOWLEDGEMENTS}

The authors are grateful to the Universiti Teknologi Malaysia, anonymous reviewer and other contributors to the paper. This study is indebted to all agencies involved in providing data and information required.

\section{REFERENCES}

Butler, G. D. (1958). Recreation areas; their design and equipment.

Butler, G. D. (1962). Standards for municipal recreation areas (G. D. Butler Ed.): National Recreation Association.

Byrne, J., \& Sipe, N. (2010). Green and open space planning for urban consolidation-A review of the literature and best practice. Issues Paper, 11 .

Byrne, J., Sipe, N., \& Searle, G. (2010). Green around the gills? The challenge of density for urban greenspace planning in SEQ. Australian Planner, 47(3), 162-177.

Cowen, T. (1992). Public Goods and Market Failures: A Critical Examinations: Transaction Publishers.

DCLG. (2002). Planning Policy Guidance 17: Planning for Open space, Sport and Recreation. United Kingdom: Department for Communities and Local Government, UK Retrieved from http://webarchive.nationalarchives.gov.uk/20120920011634/http://www.commu nities.gov.uk/archived/publications/planningandbuilding/planningpolicyguidance 17.

Givoni, B. (1991). Impact of planted areas on urban environmental quality: a review. Atmospheric Environment. Part B. Urban Atmosphere, 25(3), 289-299.

Gold, S. M. (1973). Urban recreation planning. Journal of Health, Physical Education, Recreation, 44(5), 79-79.

Haaland, C., \& van den Bosch, C. K. (2015). Challenges and strategies for urban greenspace planning in cities undergoing densification: A review. Urban Forestry \& Urban Greening, 14(4), 760-771. 
Heidt, V., \& Neef, M. (2008). Benefits of urban green space for improving urban climate. In Ecology, Planning, and Management of Urban Forests (pp. 84-96): Springer.

Ismail, N. (1999). Landskap Negara: ke arah merealisasikan Negara Taman. Towards Garden Nation: Vision and challenges. Kuala Lumpur: Institute of Landscape Architect Malaysia.

Jim, C. Y. (2004). Green-space preservation and allocation for sustainable greening of compact cities. Cities, 21(4), 311-320.

Jim, C. Y. (2013). Sustainable urban greening strategies for compact cities in developing and developed economies. Urban Ecosystems, 16(4), 741-761.

Kanniah, K. D. (2017). Quantifying green cover change for sustainable urban planning: A case of Kuala Lumpur, Malaysia. Urban Forestry \& Urban Greening, 27, 287 304.

Lee, A. C. K., Jordan, H. C., \& Horsley, J. (2015). Value of urban green spaces in promoting healthy living and wellbeing: prospects for planning. Risk management and healthcare policy, 8, 131.

Maruani, T., \& Amit-Cohen, I. (2007). Open space planning models: A review of approaches and methods. Landscape and Urban Planning, 81(1), 1-13.

Morriss, A. P., \& Meiners, R. E. (2000). The Destructive Role of Land Use Planning. Tul. Envtl. LJ, 14, 95.

Nelson, A. C. (1990). Economic critique of US prime farmland preservation policies: Towards state policies that influence productive, consumptive, and speculative value components of the farmland market to prevent urban sprawl and foster agricultural production in the United States. Journal of Rural Studies, 6(2), 119142.

Ng, E., Chen, L., Wang, Y., \& Yuan, C. (2012). A study on the cooling effects of greening in a high-density city: an experience from Hong Kong. Building and Environment, 47, 256-271.

Noor, N. M., Abdullah, A., \& Manzahani, M. N. H. (2013). Land cover change detection analysis on urban green area loss using GIS and remote sensing techniques. PLANNING MALAYSIA JOURNAL, 11(3).

PEMANDU. (2012). Annual Report 2012. Retrieved from Kuala Lumpur, Malaysia: https://www.pemandu.gov.my/assets/publications/annualreports/GTP_2012_EN.pdf

Planning Advice Note: PĀN 65: Planning and Open Space, (2008).

Shen, L., Kyllo, J. M., \& Guo, X. (2013). An integrated model based on a hierarchical indices system for monitoring and evaluating urban sustainability. Sustainability, 5(2), 524-559.

Sheng, Y. K., \& Thuzar, M. (2012). Urbanization in Southeast Asia: Issues \& Impacts: Institute of Southeast Asian Studies.

Tahir, O. M. (1997). Ke Arah Negara Taman : Wawasan Dan Cabaran, Persidangan Landskap Kebangsaan Dewan Perdana, Hotel Radisson, Shah Alam, Selangor Darul Ehsan, 4-5 November 1997. Kuala lumpur: Institut Arkitek Landskap Malaysia.

Theobald, W. (1984). A history of recreation resource planning: the origins of space standards. Leisure Studies, 3(2), 189-200. 
Robiah Suratman, Maryanti Mohd Raid, Muhammad Izuan Nadzri, Salfarina Samsudin, Nur Khairiyah Mohammad

The Implementation of Standards Approach for Open Space Planning in Kuala Lumpur

Tian, Y., Jim, C., \& Tao, Y. (2012). Challenges and strategies for greening the compact city of Hong Kong. Journal of Urban Planning and Development, 138(2), 101109.

Torkildsen, G. (2005). Leisure and recreation management: Psychology Press.

Veal, A. (2013). Open space planning standards in Australia: In search of origins. Australian Planner, 50(3), 224-232.

Vining, A. R., \& Weimer, D. L. (1992). Welfare economics as the foundation for public policy analysis: Incomplete and flawed but nevertheless desirable. The Journal of Socio-Economics, 21(1), 25-37.

Wilkinson, P. F. (1985). The golden fleece: The search for standards. Leisure Studies, 4(2), 189-203.

Wilkinson, P. F. (1988). The historical roots of urban open space planning. Leisure Studies, 7(2), 125-143.

Wong, N. H., \& Chen, Y. (2008). Tropical urban heat islands: climate, buildings and greenery: Routledge.

Yaakup, A., Ibrahim, M., Sulaiman, S., \& Sosi, Z. M. (2000). Assessment of urban development and landuse changes' impact on the environment: A case study of urban development in Klang Valley Region, Malaysia. SENVAR 2000.

Received: $15^{\text {th }}$ May 2020. Accepted: $1^{\text {st }}$ Sept 2020 